\title{
Introduction
}

\section{JACQUELINE MURRAY}

The six papers which appear in this volume of Renaissance and Reformation/ Renaissance et Réforme were originally presented at the meeting of the Canadian Society for Renaissance Studies at McMaster University. Hamilton, May 1987. The session on Sexuality in the Renaissance owed its inspiration, in part, to the pioneering volume Human Sexuality in the Middle Ages and the Renaissance, edited by Douglas Radcliff-Umstead (Pittsburgh: Center for Medieval and Renaissance Studies. University of Pittsburgh. 1978), which appeared some ten years ago. In the ensuing decade, questions pertaining to attitudes towards and perceptions of sexuality in the past have increasingly occupied the attention of scholars. This volume represents a contribution to this ongoing endeavour and adds much to our understanding of these matters.

In recent years, there have been many advances in the investigation of sexuality in the societies of the past. This area was traditionally viewed as beyond our reach. Our ancestors were reticent to discuss their attitudes and feelings about their own sexuality and often they preferred to present episodes of conventionalized abstinence or debauchery, rather than personal experience. Human sexuality, influenced as it is by societal standards and religious norms, which frequently conflict with individual appetites, is an area which encourages discretion and, ultimately, silence.

The authors of the following essays provide examples of how rigorous scholarship, innovative methodology, and an interdisciplinary approach can combine to provide information about an area of life which is both personal and governed by societal values. The complexity and inherent difficulty in the study of sexuality is found in this dialogue between the individual and society. The two interact and inform each other to a profound but essentially undefinable degree. The task of distinguishing theory from practice and romance from reality, while difficult, is an important and rewarding one.

Donald Beecher begins this task with his investigation of the medical explanations for and treatments of erotic love. In his analysis of works written by physicians who were concerned with the diagnosis and curing of love, he identifies four distinct medico-philosophical systems which in practice were combined together by physicians to form an eclectic method for the treatment of love-sickness. Professor Beecher argues that such a mingling of methodologies was a recognition by the medical profession of the complex nature of human sexuality. 
vi / Renaissance and Reformation

Massimo Ciavolella builds upon this Renaissance notion of love-sickness as a phenomenon with specific physiological symptoms and investigates the treatment of women driven mad by melancholy love. Renaissance medical opinion held that by the very nature of their bodies, women would suffer more from erotomania than would men. Indeed, erotomania could cause physiological changes within the afflicted woman, who in the worst cases underwent a sexual metamorphosis. Medical practitioners prescribed extreme treatments to halt the progress of the disease before this occurred.

The discussion moves from sexual pathology to sexual prowess with Konrad Eisenbichler's analysis of the portrait of young Guidobaldo della Rovere. By examining the specific political, social, and familial context in which the painting was commissioned, Professor Eisenbichler is able to explain the portrait's challenging iconography. Guidobaldo's bold statement of sexual virility can be seen as both an attempt to exercise his sexuality independently and as an act of rebellion against his father's marriage strategies and political ambitions.

The social controls which frustrated Guidobaldo's sexual desires are further examined by Saad El-Gabalawy. His analysis of the attitudes expressed in Renaissance libertine poetry serves to highlight the inhibitions which governed daily life. The poets exhibit a yearning for the innocent sensuality of the Golden Age, a period in which sexual expression was freed from the strictures imposed by convention and tradition. The innocent sexuality of literature stands in stark contrast to the restrictions which governed the individual's sexual practices.

It is this dissonance between theory and practice which occupies Theodore De Welles in his study of sexual attitudes in Puritan diaries. In a society which had rejected the efficacy of oral confession, diaries became a forum for recording spiritual progress and transgression, although it appears diarists were more loquacious about the sexual transgressions of others. By placing the information found in diaries against the teachings of Puritan moralists and contemporary medical opinion, Dr. De Welles concludes that Puritans saw marital sexuality as one aid on the journey to salvation: their silence was "the silence of assurance."

While Puritans may have been secure in their exercise of marital sexuality, they censured manifestations of sexuality which went beyond strictly defined limits. Valerie Lucas analyses the treatment of female transvestites by moralists, the courts, and in the literature of the period. Female transvestites threatened the very fabric of society and were an affront to the natural order. While preachers censured and courts punished such rebellious women, the writers and dramatists sought to relieve male anxiety by making female transvestites submissive wives and guardians of society's moral order. Just as doctors feared the male within, so too society feared 
the outward manifestation of the masculine-feminine. Here literature functions as a means to neutralize a sexual threat in contrast to libertine poetry's fantasy of sexual expression.

The interconnections which are apparent among these very different papers mirror the complexities of sexuality itself. Medicine and morality, theory and practice, fantasies and anxieties are all part of the collage which is human sexuality. Such interdisciplinary approaches to the study of sexuality in the past do much to increase our understanding of this most complex and fundamental aspect of human existence.

University of Toronto 